\section{Kidney \\ Blood Pressure Research}

\title{
The Enhanced Renin-Angiotensin- Aldosteron System Pharmacological Blockade - Which is the Best?
}

\author{
Leszek Tylickia Sławomir Lizakowskia Przemysław Rutkowskia,b Marcin Renke ${ }^{a, c}$

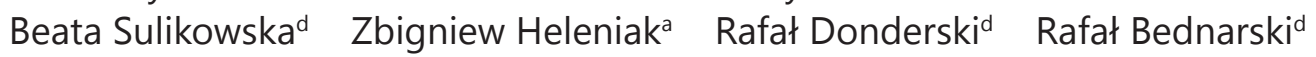 \\ Milena Przybylska ${ }^{a} \quad J a c e k$ Manitius ${ }^{d}$ Bolesław Rutkowskia
}

aDepartment of Nephrology, Transplantology and Internal Medicine. Medical University of Gdańsk. ${ }^{b}$ Department of General Nursing, Medical University of Gdańsk. 'Department of Occupational and Internal Diseases, Medical University of Gdańsk. ${ }^{\mathrm{d} D e p a r t m e n t}$ of Nephrology, Hypertension and Internal Diseases, Collegium Medicum in Bydgoszcz, Nicolaus Copernicus University Torun, Poland

\section{Key Words}

Mineralocorticoid receptor antagonist • Angiotensin II receptor antagonist • Renin inhibitor • Proteinuria • Chronic kidney disease • Renin angiotensin aldosteron system

\begin{abstract}
Background/Aims: Pharmacological inhibition of renin-angiotensin-aldosteron system (RAAS) may reduce proteinuria and the rate of chronic kidney disease progression. The aim was to compare the effects on albuminuria of the therapy with either: i) telmisartan $80 \mathrm{mg}$ and aliskiren $300 \mathrm{mg}$, ii) telmisartan $80 \mathrm{mg}$ and eplerenone $50 \mathrm{mg}$, iii) telmisartan $160 \mathrm{mg}$ as monotherapy. Design and patients: Randomized, double-center, double-blind, cross-over, three treatments-three periods of 8 weeks each study. 18 patients with non-diabetic proteinuric CKD stage 1-3 completed the protocol. Results: There was significant difference in albuminuria between studied therapies (ANOVA; $p<0.01$ ). The combination therapy with telmisartan plus aliskiren decreased albuminuria more effectively than the treatment with telmisartan plus eplerenone and monotherapy with telmisartan $160 \mathrm{mg}$ OD [376 mg/g creatinine (286-686) vs. 707 (502-1204) vs. 525 (318-763); post-hoc $p<0.01$ and $p<0.05$, respectively]. Conclusions: The study demonstrated that the combination therapy with angiotensin receptor blocker (ARB) and renin inhibitor was more effective in albuminuria lowering than the concomitant usage of ARB and mineralocorticoid receptor antagonist as well as than ARB in doses two-fold higher than usually used in treatment of hypertension in patients with non-diabetic CKD and that this higher antiproteinuric efficacy was independent on changes in blood pressure.
\end{abstract}




\section{Kidney \\ Blood Pressure Research}

Kidney Blood Press Res 2012;36:335-343

\begin{tabular}{l|l}
\hline DOI: 10.1159/000343391 & (C) 2012 S. Karger AG, Basel
\end{tabular}

Published online: December 12, 2012

www.karger.com/kbr

ylicki/Lizakowski/Rutkowski et al.: The Enhanced Renin-Angiotensin-Aldosteron System Pharmacological Blockade

\section{Introduction}

Angiotensin II and aldosterone are the key players in the development and progression of chronic kidney diseases (CKD), either directly by promoting tissue fibrosis or indirectly through their action on glomerular hemodynamic and enhancing proteinuria [1,2]. Therefore, pharmacological inhibition of the renin-angiotensin-aldosteron system (RAAS) may have a beneficial impact on renal outcome [2,3]. Various studies have shown that treatment with angiotensin-converting enzyme inhibitors (ACEI) or angiotensin II receptor blockers (ARB) reduce both proteinuria and the rate of decline in the glomerular filtration rate (GFR) in nondiabetic CKD [4-6]. Mineralocorticoid receptor antagonists and renin inhibitors have been postulated to exert antiproteinuric activity as well [7, 8]. Despite recent progress, however, there is still no optimal therapy which can stop progression of CKD. It has been shown that constant treatment with an ACEI or ARB leads to the return of angiotensin II and aldosterone to their pre-treatment level [9]. Therefore, it is necessary to search for therapeutic strategy which can enhance RAAS blockade and further improve renal outcome. Of particular need is to find the optimal combination of different RAAS blocking drugs and establish the optimal dosing of these agents [10]. To gain insight into this issue, we performed the study to compare the influence of (i) the combination therapy with ARB, telmisartan plus renin inhibitor, aliskiren, (ii) the combination therapy with ARB, telmisartan plus mineralocorticoid receptor antagonist, eplerenone and (iii) monotherapy with ARB, telmisartan in doses twofold higher than usually used on albuminuria regarded as an independent risk factor for renal disease progression and a surrogate marker of kidney injury extent.

\section{Material and Methods}

\section{Individuals}

Patients were selected from the cohort that attended renal outpatients' departments in Medical University of Gdansk and Collegium Medicum in Bydgoszcz of Nicolaus Copernicus University in Torun. The inclusion criteria were established as follows: age 18-65 years, non-diabetic proteinuric chronic kidney disease stage 1-3, stable proteinuria above $500 \mathrm{mg} / 24$ hours in last 6 months (no variations above 500 $\mathrm{mg} / 24$ hours), hypertension treated with at least one agent or hypertension no treated so far with blood pressure above $140 / 90 \mathrm{mmHg}$, no steroids or other immunosuppressive treatment for a minimum of six months before the study. Patients with unstable coronary heart disease or decompensated congestive heart failure in the previous 6 months, with an episode of malignant hypertension or stroke in the history, diabetics and estimated glomerular filtration rate of less than $30 \mathrm{ml}$ per minute per $1.73 \mathrm{~m}^{2}$ of body-surface area were excluded.

\section{General protocol}

This was a double center, prospective, randomized, double-blind, cross-over study comparing the renal effects of therapy with either combination of telmisartan $80 \mathrm{mg}$ and eplerenone $50 \mathrm{mg}$ OD (A), or the combination of telmisartan $80 \mathrm{mg}$ and aliskiren $300 \mathrm{mg}$ OD (B), or telmisartan $160 \mathrm{mg}$ OD (C) alone, in three randomized periods of 8 weeks each. At the beginning, subjects who met the inclusion criteria entered the 8 weeks run-in period during which any hypotensive agents previously used were stopped and blood pressure (BP) was controlled by the background therapy with combination of telmisartan $80 \mathrm{mg}$ and ACEI, perindopril $10 \mathrm{mg} O D$ (P1 period). At the end of the run-in period, the subjects were randomly allocated to one of six treatment sequences: $\mathrm{ABC}, \mathrm{ACB}, \mathrm{BAC}, \mathrm{BCA}, \mathrm{CAB}, \mathrm{CBA}$ (Figure 1). Allocation was performed according to a computer generated randomization list. For the ethical reasons there was no washout between the run-in period and three treatment therapies. There was also no washout between the treatments in each sequence. At the end, the same 8-week background therapy as in the run-in period was administered as a control period for stability of the background proteinuria (P5 period). Preparing, labeling and blinding of the study medications was performed by Department of Pharmaceutical Technology, Medical University of Gdańsk. Patients were instructed to take the study medication once daily in the morning. The doses of the study medications were not changed. Patients were recommended not to change their usual daily protein 


\section{Kidney Blood Pressure Research}

Fig. 1. Study protocol.

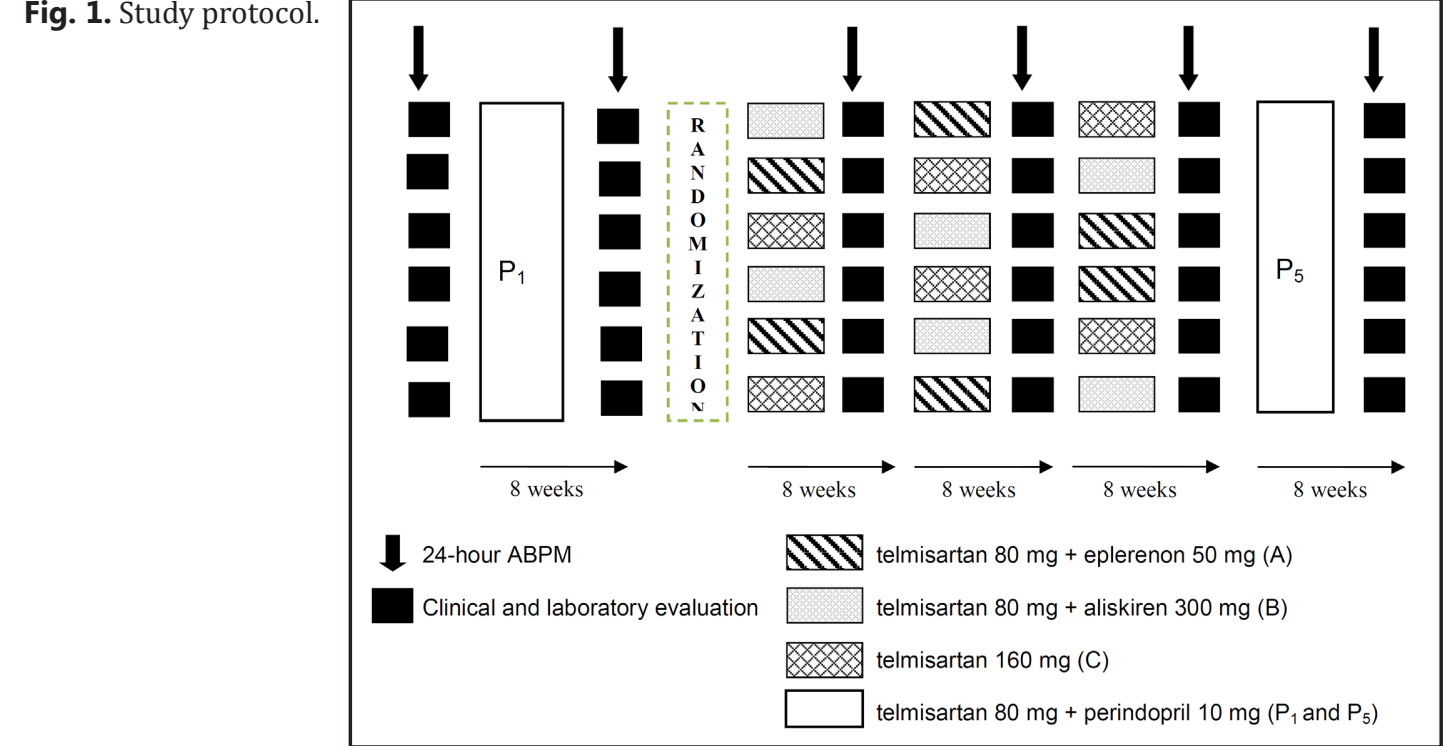

and sodium intake during the study period. At the end of each of 3 treatment periods $(\mathrm{A}, \mathrm{B}, \mathrm{C})$ and after both background therapies (P1 and P5) albuminuria, ambulatory BP, serum concentration of creatinine were determinated and creatinine clearance was calculated. Patients discontinued the trial in case of withdrawal of consent, incompliance with therapy, hyperkalaemia $(>6.0 \mathrm{mmol} / \mathrm{l})$, worsening of renal function defined by an increase from baseline serum creatinine greater than $30 \%$ and confirmed in two occasions, any other severe adverse events associated with treatment, e.g. cough or angioedema on ACEIs therapy. The study was approved by the local ethical committee, and the investigated patients all gave their informed consent. The study was registered at www.clinicaltrial.gov (identifier: NCT 01541267).

\section{Procedures and laboratory analyses}

Ambulatory BP was measured continuously for 24-h using the Mobil-o-graph (version 12) monitoring system. BP was measured every 15 minutes during the day ( 7.00 a.m. to 10.00 p.m.) and every 30 minutes during the night (10.00 p.m. to 7.00 a.m.). Results of ambulatory BP measurements were analysed for $24 \mathrm{~h}$ SBP, 24h DBP.

Albumin urine excretion was measured in the first morning spot urine sample and expressed as the ratio of albumin-to-creatinine (UACR) to correct for variations in urinary concentration due to hydration. Two urine sample were collected on separate days - of those the mean value of UACR was calculated for data evaluation. The concentration of albumin was measured by enzyme-linked immunosorbent assay (ELISA) using an Albumin (Immunodiagnostic AG, Bensheim, Germany) kit in accordance with manufacturer's recommendations. The intra-assay and inter-assay coefficients of variations for this assay were $5.0 \%$ and $8.0 \%$, respectively. Creatinine level was measured in the same urine samples using a modified kinetic Jaffe method.

Serum creatinine was measured by the standard laboratory techniques. Sodium $(\mathrm{Na})$ and urea excretion were evaluated on the basis of 24-hour urine collection. The excretion of urea was used to calculate the protein intake according to Maroni equation : protein intake normalized to weight $(\mathrm{g} / \mathrm{kg} / \mathrm{day})=6.25 \mathrm{x}[($ urea$\mathrm{N}$-excretion urine $24 \mathrm{~h}(\mathrm{~g} /$ day $)+(0.0031$ xbody weight $(\mathrm{kg}))] /$ body weight $(\mathrm{kg})$ [11]. Creatinine clearance was calculated according to Cockroft-Gault equation [12].

\section{Statistics}

The primary end point of the study was a difference in albuminuria between three studied therapies. A sample size of 18 patients adequately allowed a power of $80 \%$ to detect a difference in means across the levels of repeated measures factor equal to within patient standard deviation, that is a standardised effect size of 1.0 at a significance level of 0.05 (two-tailed). Normality and homogeneity of the variances were verified by means of the Shapiro-Wilk test and Levene test, respectively. In the per-protocol design, the variable differences were assessed by analysis of variance (ANOVA) for repeated measurements with 


\section{Kidney \\ Blood Pressure Research}

Table 1: Patients`characteristic at baseline

\begin{tabular}{|c|c|}
\hline \multicolumn{2}{|l|}{ Parameter } \\
\hline n (Gender: female/male $n$ ) & $18(4 / 14)$ \\
\hline Age years & $39.3 \pm 2.7$ \\
\hline Mean systolic blood pressure $\mathrm{mm} \mathrm{Hg}$ & $116.8 \pm 2,4$ \\
\hline Mean diastolic blood pressure $\mathrm{mm} \mathrm{Hg}$ & $73.8 \pm 1.8$ \\
\hline $24 \mathrm{~h}$ proteinuria $g$ & $1.62(0.98-2.26)$ \\
\hline Serum creatinine $m g / d l$ & $1.1 \pm 0.11$ \\
\hline Creatinine clearence [Cockroft-Gault formula] $\mathrm{ml} / \mathrm{min}$ & $94.0 \pm 8.1$ \\
\hline 24-hour urinary sodium $\mathrm{mmol} / 24 \mathrm{~h}$ & $169 \pm 21$ \\
\hline Serum potasium $\mathrm{mmol} / \mathrm{l}$ & $4.47 \pm 0.1$ \\
\hline Body mass index $\mathrm{kg} / \mathrm{m}^{2}$ & $26.4 \pm 0.79$ \\
\hline \multicolumn{2}{|l|}{ Diagnosis : $n$} \\
\hline Mesangial glomerulonephritis & 2 \\
\hline Mesangiocapillary glomerulonephritis & 2 \\
\hline Membranous glomerulonephritis & 2 \\
\hline Focal segmental glomerulonephritis & 3 \\
\hline Minimal change nephropathy & 1 \\
\hline IgA nephropathy & 6 \\
\hline Unknown non-diabetic proteinuric chronic kidney diseases & 2 \\
\hline \multicolumn{2}{|l|}{ Background hypotensive therapy: $n$} \\
\hline ACEi and ARB & $8(44.5 \%)$ \\
\hline ACEi (alone) & $4(22.5 \%)$ \\
\hline $\mathrm{ARB}$ (alone) & $2(11 \%)$ \\
\hline No hypotensive therapy & $4(22 \%)$ \\
\hline \multicolumn{2}{|c|}{$\begin{array}{l}\text { ACEi - angiotensin-converting enzyme inhibitors; ARB - angiotensin II receptor blockers; } \\
\text { Note: To convert serum creatinine in mg/dL to } \mu \mathrm{mol} / \mathrm{L} \text {, multiply by } 88.4 \text {; eGFR in } \\
\mathrm{mL} / \mathrm{min} / 1.73 \mathrm{~m} 2 \text { to } \mathrm{mL} / \mathrm{s} / 1.73 \mathrm{~m} 2 \text {, multiply by } 0.01667 \text {; Data are expressed as mean } \pm \mathrm{SEM} \\
\text { or geometric mean }(95 \% \text { confidence interval) }\end{array}$} \\
\hline
\end{tabular}

Benferroni corrections for paired comparisons. Head to head comparisons between study therapies and background treatment with telmisartan plus perindopril, as secondary analyses, were performed using t-Student test. A $P<0.05$ (two-tailed) was considered statistically significant. Data were evaluated using a STATISTICA (version 9.0 Stat Soft Inc.) software package. The results were expressed as means \pm SEM.

To prevent or limit the risk of "carryover" effect, we planned each treatment period for 8 weeks. Previous studies demonstrated that the effects of RAAS blocking agents on albuminuria and glomerular permselectivity are fully reversible within 4 weeks [13]. Thus, prolonging each treatment period to 8 weeks allowed us to rule out any residual effect of previous treatment at the end of the eighth week, when albuminuria was measured. To prevent or limit the possibility of a "period effect", we introduced a degree of balance into the study design, with a scheme of randomisation allowing every treatment sequence to be represented in every period with the same frequency. Overall, we had six different therapy sequences with the three treatment periods (Figure 1). Equal numbers of patients $(n=3)$ per sequence were randomised. Since no patients were prematurely withdrawn, this balance was fully respected at the study end. To test the presence of "period effect", the difference between albuminuria at the end of P1 and P5 periods was checked.

\section{Results}

Of the 18 patients who entered the study, 18 (100\%) completed the protocol. Baseline clinical characteristic of patients is listed in Table 1. Before data analysis, the "period effect" (the difference in UACR after P1 and P5 period) was tested and found not to be significant.

\section{4 hour ambulatory $B P$}

There were no differences in systolic and diastolic blood pressure between the treatments (Table 2) BP was stable during whole study time without hyper- and hypotonic episodes. 


\section{Kidney \\ Blood Pressure Research}

Tylicki/Lizakowski/Rutkowski et al.: The Enhanced Renin-Angiotensin-Aldosteron System Pharmacological Blockade

Table 2: 24 h systemic blood pressure and laboratory results during the study

\begin{tabular}{lcccccc}
\hline & $\begin{array}{c}\text { Telsmisartan } \\
\text { Perindopril } \\
(\mathrm{P} 1)\end{array}$ & $\begin{array}{c}\text { Telmisartan } \\
\text { Eplerenon } \\
(\mathbf{A})\end{array}$ & $\begin{array}{c}\text { Telmisartan } \\
\text { Aliskiren } \\
(\mathbf{B})\end{array}$ & $\begin{array}{c}\text { Telmisartan } \\
\mathbf{1 6 0} \\
(\mathbf{C})\end{array}$ & $\begin{array}{c}\text { Telsmisartan } \\
\text { Perindopril } \\
(\text { P2) }\end{array}$ & $\begin{array}{c}\text { ANOVA } \\
\text { (A vs B vs C) }\end{array}$ \\
\hline Systolic BP (24h) $\mathrm{mmHg}$ & $116.8 \pm 2.4$ & $121.5 \pm 2.6$ & $120.5 \pm 2.8$ & $120.6 \pm 2.4$ & $118.0 \pm 2.4$ & $\mathrm{p}=0.86$ \\
Diastolic BP $(24 \mathrm{~h}) \mathrm{mmHg}$ & $79.9 \pm 1.8$ & $76.6 \pm 1.9$ & $74.4 \pm 2.2$ & $75.8 \pm 2.0$ & $73.8 \pm 1.6$ & $\mathrm{p}=0.31$ \\
$\mathrm{CrCl}[\mathrm{C}-\mathrm{G}] \mathrm{ml} / \mathrm{min}$ & $94.1 \pm 8.1$ & $97.3 \pm 8.1$ & $96.6 \pm 8.2$ & $97.9 \pm 8.3$ & $97.7 \pm 8.6$ & $\mathrm{p}=0.73$ \\
Daily protein intake $\mathrm{g} / \mathrm{kg} / 24 \mathrm{~h}$ & $1.05 \pm 0.23$ & $0.98 \pm 0.25$ & $0.97 \pm 0.28$ & $1.0 \pm 0.18$ & $0.98 \pm 0.29$ & $\mathrm{p}=0.65$ \\
Sodium urine excretion $\mathrm{mmol} / 24 \mathrm{~h}$ & $169 \pm 21$ & $170 \pm 17$ & $194 \pm 22$ & $194 \pm 22$ & $173 \pm 20$ & $\mathrm{p}=0.25$ \\
Serum potassium $\mathrm{mmol} / \mathrm{l}$ & $4.47 \pm 0.1$ & $4.28 \pm 0.08$ & $4.56 \pm 0.13$ & $4.45 \pm 0.1$ & $4.43 \pm 0.11$ & $\mathrm{p}=0.58$ \\
\hline
\end{tabular}

Data are expressed as mean \pm SEM. BP - blood pressure; $\mathrm{ClCr}$ CG - Creatinine clearance (Cockroft-Gault formula)

Fig. 2. Urinary albumin-to-creatinine (UACR) ratio during the study. $\mathrm{P}_{1}$ and $\mathrm{P}_{5}-$ telmisartan $80 \mathrm{mg}+$ perindopril $10 \mathrm{mg}$; A - telmisartan $80 \mathrm{mg}$ + eplerenone $50 \mathrm{mg}$, B - telmisartan 80 mg + aliskiren 300 mg, C - telmisartan $160 \mathrm{mg}$; $\mathrm{p}<0.05$ vs $\mathrm{P}_{1}(\mathrm{t}-$ Student $)$ and $\mathrm{P}_{5}$ (t-Student).

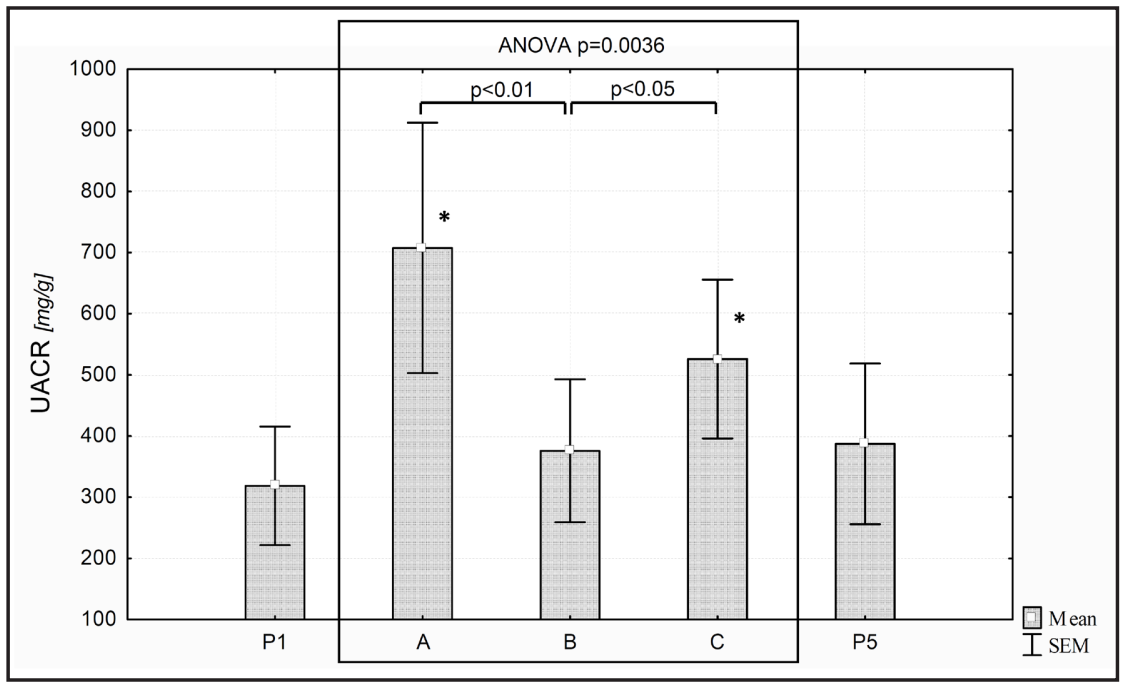

\section{Albuminuria}

There was significant difference in UACR between studied therapies (ANOVA; $\mathrm{p}<0.01$ ). The combination therapy with telmisartan plus aliskiren decreased UACR [376 mg/g (95\% CI (286-686)] more effectively than the combination therapy with telmisartan plus eplerenone [707 mg/g (95\% CI 502-1204)]; (post-hoc $\mathrm{p}<0.01)$ and monotherapy with telmisartan 160 mg [(525 (95\% CI 318-763)]; (post-hoc p<0.05) (Figure 2).

In 10 of 18 (55.5\%) patients, the lowest UACR was achieved with telmisartan plus aliskiren treatment, in further 5 subjects $(27.8 \%)$ with telmisartan $160 \mathrm{mg}$ therapy and in further 3 patients $(17.2 \%)$ with the combination telmisartan plus eplerenone.

In secondary analyses, the background therapy with telmisartan and perindopril was found to decrease UACR [318 mg/g (95\% CI; 237-539)] more effectively than the combination therapy with telmisartan plus eplerenone ( $t$-Student; $\mathrm{p}<0.05$ ) and monotherapy with telmisartan $160 \mathrm{mg}$ ( $\mathrm{t}$-Student; $\mathrm{p}<0.05$ ). There was no difference between the background therapy with telmisartan and perindopril and the combination therapy with telmisartan and aliskiren.

\section{Renal function, sodium and protein intake}

Renal function assessed by means of estimated creatinine clearance remained stable during the study. There were no differences in sodium and protein intake between treatment periods (Table 2).

Adverse effect

All therapies were well tolerated by patients. Adverse effects were not reported. 


\section{Kidney Blood Pressure Research}

Kidney Blood Press Res 2012;36:335-343

\begin{tabular}{l|l}
\hline DOI: $10.1159 / 000343391$ & (C) 2012 S. Karger AG, Basel
\end{tabular}

Published online: December 12, 2012

www.karger.com/kbr

ylicki/Lizakowski/Rutkowski et al.: The Enhanced Renin-Angiotensin-Aldosteron System Pharmacological Blockade

\section{Discussion}

Several large randomized, controlled trials evidenced the renoprotective potential of the ACEIs and ARBs in nephropathies of almost any etiology [10]. In non-diabetic renal diseases, ACEIs are currently the best documented treatment to delay the progression of nephropathy. The strongest evidence was provided by the results of REIN study, in which, ramipril treatment resulted in a slower decline in GFR compared with placebo $[14,15]$. The interim analysis of AASK trial demonstrated that the renoprotective effect of ACEI is superior to that of conventional antihypertensive regimens including $\beta$-blockers and calcium channel blockers [16]. Although several studies including the authors' findings have shown that treatment with ARBs significantly reduces proteinuria in the extent comparable to ACEIs $[6,17]$, an direct evidence for benefit from ARBs in nondiabetic renal disease has not been provided to date.

Despite great progress in the nephroprotecitve therapy of chronic nephropathies and a decrease in their progression rate by accurate RAAS blockade, it has not proved possible to inhibit their progress completely. The reasons may reflect the fact that monotherapy does not provide complete and persistent blockade of the RAAS system [18]. It has been also shown that constant treatment with an ACEIs or an ARBs eventually leads to the return of angiotensin II and aldosterone to their pretreatment level after some time of such therapy (escape phenomenon) [9].

Different methods of enhanced RAAS blockade involving the concomitant usage of two agents inhibiting RASS from different groups or increasing dosage of ACEI or ARB above their therapeutic range lead to more complete RAAS blockade and stronger antiproteinuric effects [10]. Several clinical studies have investigated dual RAAS blockade with ACEI and ARB in non-diabetic or mixed renal patients and documented a greater antiproteinuric effect of combined therapy with ACEIs and ARBs than with monotherapy with these agents [1922]. The combination of a specific mineralocorticoid receptor antagonists, spironolactone or eplerenone and ACEI was more effective in reducing albuminuria/proteinuria in patients with nondiabetic CKD than ACEI alone [23, 24]. Previously, we showed that administration of mineralocorticoid receptor antagonist, spironolactone in addition to double RAAS blockade with an ACEI and ARB may reduce further residual proteinuria [25]. Similar properties seems to exert direct renin inhibitors as a part of combination strategies. Aliskiren as addon treatment to standard therapy including the optimal dose of the ARB, losartan, in the AVOID study, reduced albuminuria and slowed development of renal dysfunction more than placebo across different levels of eGFR in patients with type 2 diabetes, hypertension, and nephropathy [26]. Adequate uptitration of the dose of ARBs to values well above those usually recommended to lower blood pressure is hypothesized to decrease proteinuria further and slow the progression glomerular filtration loss [27, 28]. It is not clear, however, which strategy is the best for the renal outcome.

The study involved nondiabetic proteinuric patients with hypertension and quite normal renal function. The study demonstrated that the combination with telmisartan and aliskiren produces a more profound decrease in albuminuria than monotherapy with telmisartan in high doses and the combination with telmisartan and eplerenon. Our study had enough power to detect significant difference in antiproteinuric effect between three studied therapies and it is unlikely that other factors might influence on the outcome. The three treatment periods did not differ with respect to blood pressure, patients' sodium and protein intake as well as renal function. In secondary analyses the antiproteinuric activity of the combination of telmisartan plus aliskiren was shown to be quite as effective as the combination telmisartan plus ACEI, perindopril. The later finding, however, should be confirmed in randomized studies.

The question arises as to whether the study results provides the answer for the question which the RAAS blockade is the best for long term renal outcome. The combination with telmisartan plus aliskiren seems to the best as long as surrogate marker of kidney injuries i.e. albuminuria is taken into account. Whether the stronger expressed reduction of albuminuria 


\section{Kidney \\ Blood Pressure Research}

Kidney Blood Press Res 2012;36:335-343

\begin{tabular}{l|l}
\hline DOI: 10.1159/000343391 & (C) 2012 S. Karger AG, Basel
\end{tabular}

Published online: December 12, 2012

www.karger.com/kbr

Pharmacological Blockade

translates into meaningful outcomes for CKD is unknown. On should also take into account the fact that the long-term effects of high doses of ACEI or ARB or addition of eplerenon, especially for fibrotic process, may be seen after longer period than observed in the study [29-31]. Until we know the answer to these questions, only those with very high level of proteinuria and normal renal function may be offered with the combination of telmisartan and aliskiren and need to be carefully monitored for hyperkalemia and worsening of kidney function. One should also remember that quite recently ALTITUDE study performed in diabetics was terminated early for lack of efficacy and risk of renal impairment, hyperkalemia and nonfatal stroke in patients taking aliskiren plus ACEI or ARB [32]. In response to these findings FDA recommended not to use such drug combination in patients with diabetes or renal insufficiency until results from other aliskiren trials will become available. Also, greater reduction in albuminuria not always translates into better long-term kidney outcome as was shown in ONTARGET study showing higher risk of acute kidney injuries and hyperkaliemia in patients treated with double RAAS blockade using ACEI and ARB [33].

The studied treatments were well tolerated. There were no differences in serum potassium concentration across studied therapies. One should take into account, however, that only patients with normal kidney function receiving low-potassium diet were included to the study. Despite these results one should be aware that pharmacological RAAS blockade may result in hyperkaliemia incidence, especially in case of enhanced RAAS blockade e.g. concomitant usage of two or three drugs [34,35].

\section{Conclusion}

The study demonstrated that the combination therapy with ARB and renin inhibitor was more effective in albuminuria lowering than the concomitant usage of ARB and mineralocorticoid receptor antagonist as well as than ARB in doses two-fold higher than usually used in treatment of hypertension in patients with non-diabetic CKD and that this higher antiproteinuric efficacy was independent on changes in blood pressure.

\section{Conflict of Interests}

The authors have no conflicts of interest to declare.

\section{References}

1 Nakamura T, Fujiwara N, Sato E, Ueda Y, Sugaya T, Koide H: Renoprotective effects of various angiotensin II receptor blockers in patients with early-stage diabetic nephropathy. Kidney Blood Press Res 2010;33:213220.

2 Tylicki L, Larczynski W, Rutkowski B: Renal protective effects of the renin-angiotensin-aldosterone system blockade: From evidence-based approach to perspectives. Kidney Blood Press Res 2005;28:230-242.

-3 Siamopoulos KC, Kalaitzidis RG: Inhibition of the renin-angiotensin system and chronic kidney disease. Int Urol Nephrol 2008;40:1015-1025.

-4 The Gisen group (Gruppo Italiano Di Studi Epidemiologici in Nefrologia): Randomised placebo-controlled trial of effects of ramipril on decline in glomerular filatration rate and risk of terminal renal failure in proteinuric, non-diabetic nephropathy. Lancet 1997;349:1857-1863.

5 Maschio G, Alberti D, Janin G, Locatelli F, Mann JF, Motolese M, Ponticelli C, Ritz E, Zucchelli P: Effect of the angiotensin-converting-enzyme inhibitor benazepril on the progression of chronic renal insufficiency. The angiotensin-converting-enzyme inhibition in progressive renal insufficiency study group. N Engl J Med 1996;334:939-945. 


\section{Kidney \\ Blood Pressure Research}

Kidney Blood Press Res 2012;36:335-343

\begin{tabular}{l|l}
\hline DOI: $10.1159 / 000343391$ & (c 2012 S. Karger AG, Basel
\end{tabular}

Published online: December 12, 2012

www.karger.com/kbr

Tylicki/Lizakowski/Rutkowski et al.: The Enhanced Renin-Angiotensin-Aldosteron System Pharmacological Blockade

6 Tylicki L, Rutkowski P, Renke M, Rutkowski B: Renoprotective effect of small doses of losartan and enalapril in patients with primary glomerulonephritis. Am J Nephrol 2002;22:356-362.

7 Bianchi S, Bigazzi R, Campese VM: Antagonists of aldosterone and proteinuria in patients with CKD: An uncontrolled pilot study. Am J Kidney Dis 2005;36:45-51.

8 Lizakowski S, Tylicki L, Renke M, Rutkowski P, Heleniak Z, Slawinska Morawska M, Aleksandrowicz Wrona E, Lysiak-Szydlowska W, Rutkowski B: The effect of aliskiren on proteinuria in chronic nondiabetic kidney disease: A double-blind cross-over randomised controlled trial. Int Urol Nephrol 2012; in press.

-9 Shiigai T, Shichiri M: Late escape from the antiproteinuric effect of ACE inhibitors in nodiabetic disease. Am J Kidney Dis 2001;2001:477-483.

-10 Tylicki L, Lizakowski S, Rutkowski B: Renin-angiotensin-aldosterone system blockade for nephroprotection: Current evidence and future directions. J Nephrol 2012;25:900-910.

11 Maroni BJ, Steinman TI, Mitch WE: A method for estimating nitrogen intake of patients with chronic renal failure. Kidney Int 1985;27:58-65.

12 Cockcroft DW, Gault MH: Prediction of creatinine clearance from serum creatinine. Nephron 1976;16:3141.

13 Gansevoort R, De Zeeuw D, De Jong P: Is the antiproteinuric effect of ACE inhibition mediated by interference in the renin-angiotensin system ? Kidney Int 1994;45:861-867.

14 Ruggenenti P, Perna A, Gheradi G, Garini G, Zoccali C, Salvadori M, Scolari F, Schena F, Remuzzi G: Renoprtective properties of ace-inhibition in non-diabetic nephropathies with non-nephrotic proteinuria. Lancet 1999;354:359-364.

15 Ruggenenti P, Perna A, Gherardi G, Gaspari F, Benini R, Remuzzi G: Renal function and requirement for dialysis in chronic nephropathy patients on long-term ramipril: REIN follow-up trial. Gruppo Italiano di Studi Epidemiologici in Nefrologia (Gisen). Ramipril efficacy in nephropathy. Lancet 1998;352:1252-1256.

-16 Agodoa LY, Appel L, Bakris GL, Beck G, Bourgoignie J, Briggs JP, Charleston J, Cheek D, Cleveland W, Douglas JG, Douglas M, Dowie D, Faulkner M, Gabriel A, Gassman J, Greene T, Hall Y, Hebert L, Hiremath L, Jamerson K, Johnson CJ, Kopple J, Kusek J, Lash J, Lea J, Lewis JB, Lipkowitz M, Massry S, Middleton J, Miller ER, 3rd, Norris K, O'Connor D, Ojo A, Phillips RA, Pogue V, Rahman M, Randall OS, Rostand S, Schulman G, Smith W, Thornley-Brown D, Tisher CC, Toto RD, Wright JT, Jr., Xu S: Effect of ramipril vs amlodipine on renal outcomes in hypertensive nephrosclerosis: A randomized controlled trial. JAMA 2001;285:2719-2728.

17 Tylicki L, Renke M, Rutkowski P, Rutkowski B, Lysiak-Szydlowska W: Randomized, controlled study of the effects of losartan versus enalapril in small doses on proteinuria and tubular injury in primary glomerulonephritis. Med Sci Monit 2005;11:PI31-PI37.

18 Forclaz A, Maillard M, Nussberger J, Brunner HR, Burnier M: Angiotensin II receptor blockade: Is there truly a benefit of adding an ACE inhibitor? Hypertension 2003;41:31-36.

19 Campbel R, Sangalli F, Perticuccu E, Aros C, Viscarra C, Perna A, Remuzzi A, Bertocchi F, Fagiani L, Remuzzi G, Ruggenenti P: Effects of combined ace inhibitor and angiotensin II antagonist treatment in human chronic nephropathies. Kidney Int 2003;63:1094-1103.

-20 Laverman G, Navis G, Henning R, De Jong P, De Zeeuw D: Dual renin-angiotensin system blockade at optimal doses for proteinuria. Kidney Int 2002;62:1020-1025.

-21 Russo D, Pisani A, Balletta M, De Nicola L, Savino F, Andreucci M, Minutolo R: Additive antiproteinuric effect of converting enzyme inhibitor and losartan in normotensive patients with IgA nephropathy. Am J Kidney Dis 1999;33:851-856.

-22 Rutkowski P, Tylicki L, Renke M, Korejwo G, Zdrojewski Z, Rutkowski B: Low-dose dual blockade of the renin-angiotensin system in patients with primary glomerulonephritis. Am J Kidney Dis 2004;43:260-268

23 Chrysostomou A, Becker G: Spironolactone in addition to ace inhibition to reduce proteinuria in patients with chronic renal disease. N Engl J Med 2001;345:925-926.

-24 Pitt B, Reichek N, Willenbrock R, Zannad F, Phillips RA, Roniker B, Kleiman J, Krause S, Burns D, Williams GH: Effects of eplerenone, enalapril, and eplerenone/enalapril in patients with essential hypertension and left ventricular hypertrophy: The 4E-LEFT ventricular hypertrophy study. Circulation 2003;108:18311838.

25 Tylicki L, Rutkowski P, Renke M, Larczynski W, Aleksandrowicz E, Lysiak-Szydlowska W, Rutkowski B: Triple pharmacological blockade of the renin-angiotensin-aldosterone system in nondiabetic CKD: An open-label crossover randomized controlled trial. Am J Kidney Dis 2008;52:486-493. 


\section{Kidney \\ Blood Pressure Research}

Kidney Blood Press Res 2012;36:335-343

DOI: 10.1159/000343391

Published online: December 12, 2012

(C) 2012 S. Karger AG, Basel

www.karger.com/kbr

Tylicki/Lizakowski/Rutkowski et al.: The Enhanced Renin-Angiotensin-Aldosteron System Pharmacological Blockade

-26 Parving HH, Persson F, Lewis JB, Lewis EJ, Hollenberg NK: Aliskiren combined with losartan in type 2 diabetes and nephropathy. N Engl J Med 2008;358:2433-2446.

-27 Aranda P, Segura J, Ruilope LM, Aranda FJ, Frutos MA, Lopez V, Lopez de Novales E: Long-term renoprotective effects of standard versus high doses of telmisartan in hypertensive nondiabetic nephropathies. Am J Kidney Dis 2005;46:1074-1079.

-28 Schmieder RE, Klingbeil AU, Fleischmann EH, Veelken R, Delles C: Additional antiproteinuric effect of ultrahigh dose candesartan: A double-blind, randomized, prospective study. J Am Soc Nephrol 2005;16:3038-3045.

-29 Adamczak M, Gross M, Krtil J, Koch A, Tyralla K, Amann K, Ritz E: Reversal of glomerulosclerosis after highdose enalapril treatment in subtotally nephrectomized rats. J Am Soc Nephrol 2003;14:2833-2842.

30 Aldigier JC, Kanjanbuch T, Ma LJ, Brown NJ, Fogo AB: Regression of existing glomerulosclerosis by inhibition of aldosterone. J Am Soc Nephrol 2005;16:3306-3314.

-31 Ma LJ, Nakamura S, Aldigier JC, Rossini M, Yang H, Liang X, Nakamura I, Marcantoni C, Fogo AB: Regression of glomerulosclerosis with high-dose angiotensin inhibition is linked to decreased plasminogen activator inhibitor-1. J Am Soc Nephrol 2005;16:966-976.

32 Parving HH, Brenner BM, McMurray JJ, de Zeeuw D, Haffner SM, Solomon SD, Chaturvedi N, Persson F, Desai AS, Nicolaides M, Richard A, Xiang Z, Brunel P, Pfeffer MA: Cardiorenal end points in a trial of aliskiren for type 2 diabetes. N Engl J Med DOI: 10.1056/NEJMoa1208799.

-33 Mann JF, Schmieder RE, McQueen M, Dyal L, Schumacher H, Pogue J, Wang X, Maggioni A, Budaj A, Chaithiraphan S, Dickstein K, Keltai M, Metsarinne K, Oto A, Parkhomenko A, Piegas LS, Svendsen TL, Teo KK, Yusuf S: Renal outcomes with telmisartan, ramipril, or both, in people at high vascular risk (The ONTARGET study): A multicentre, randomised, double-blind, controlled trial. Lancet 2008;372:547-553.

-34 Navaneethan SD, Nigwekar SU, Sehgal AR, Strippoli GF: Aldosterone antagonists for preventing the progression of chronic kidney disease: A systematic review and meta-analysis. Clin J Am Soc Nephrol 2009;4:542-551.

35 Toto RD: RAS blockade, hyperkalemia and AKI-look and you will find. Nat Rev Nephrol 2012;8:257-258. 